\title{
Design Considerations for Large W oody Debris Placement in Stream Enhancement Projects
}

\author{
R obert H. Hilderbrand ${ }^{1.2}$ \\ Department of Fisheries and Wildife Sciences \\ Virginia Polytechnic Institute and State University, Blacksburg, Virginia 24061-0321, USA \\ A. Dennis lemly and C. Andrew Dolloff \\ U.S. Forest Service, Southern Research Station \\ Coldwater Fisheries Research Unit, Blacksburg, Virginia, 24061-0321, USA \\ Kelly L. HaRPSTER \\ Department of Fisheries and Wildlife Sciences \\ Virginia Polytechnic Institute and State University, Blacksburg, Virginia 24061-0321, USA
}

\begin{abstract}
Log length exerted a critical influence in stabilizing large woody debris (LWD) pieces added as an experimental stream restoration technique. Logs longer than the average bank-full channel width $(5.5 \mathrm{~m})$ were significantly less likely to be displaced than logs shorter than this width. The longest $\log$ in stable $\log$ groups was significantly longer than the longest log in unstable groups. The distances moved by displaced $\operatorname{logs}$ demonstrated a quadratic relationship associated with log length; longer logs moved less often, but they moved farther when entrained in the current than the majority of mobile smaller logs. Log stability did not differ between a treatment section with randomized placement of LWD and a section in which LWD was placed systematically to best modify channel habitats. Channel scouring typically occurred around LWD oriented as ramps and as dams perpendicular to stream flow; aggradation occurred above and below pieces oriented as dams angled to the current. Microscale channel responses to LWD additions varied.
\end{abstract}

Large woody debris (LWD) links the terrestrial and aquatic portions of many headwater systems (Triska and Cromack 1980). It influences channel morphology (Keller and Swanson 1979; Bilby 1984; Robison and Beschta 1990), provides habitat structure for fish (Dolloff 1986; Bisson et al. 1987) and aquatic invertebrates (Anderson et al. 1978; O'Connor 1991), and promotes storage of sediments (Megahan 1982) and organic matter (Bilby and Likens 1980; Speaker et al. 1984; Smock et al. 1989; Trotter 1990).

Numerous factors may influence LWD's spatial stability and effects on stream channels. In a flume study, Beschta (1983) found that large pieces or aggregations of LWD suspended above a streambed induced longer and deeper pools than small single pieces. Bilby and Ward (1989) found a positive correlation between pool area and the volume of the debris piece forming natural pools, and Carlson et al. (1990) reported that multiple pieces were

\footnotetext{
1 Corresponding author: slx0q.@cc.usu.edu

2 Present address: Department of Fisheries and Wildlife and The Ecology Center, Utah State University, Logan, Utah 84322-5210, USA.
}

more often associated with pool formation than individual pieces.

Cherry and Beschta (1989) used small wooden dowels 1 to $10 \%$ the size of real $\operatorname{logs}$ to simulate scour in a sand-filled, 6.1-m X 0.4-m flume. Dowels oriented upstream caused major flow disturbances and large scour depths that decreased bank stability. Dowels oriented downstream or perpendicular to the flow increased bank stability relative to the upstream oriented pieces. The authors hypothesized that pieces oriented perpendicular or downstream to flow require less anchoring than upstream-oriented $\operatorname{logs}$ to maintain position at various flows. In natural streams, thalweg position or the presence of other logs undoubtedly affects local channel patterns around any given piece of LWD, but we know of no information on the subject. Stability of LWD is positively related to $\log$ length (Bilby 1984; Lienkaemper and Swanson 1987; Robison and Beschta 1990), but the influences of other factors such as channel curvature or whether a $\log$ lies in a pool or a riffle are unknown.

Many authors have reported orientations of LWD and inferred pool characteristics from wood orientation, but few have examined the processes 
of channel bed adjustment to LWD and of pool formation. Bilby (1984) reported that selective removal of LWD pieces brought debris instability, channel scouring, and loss of many pools through filling or channel rerouting; pools reformed after the remaining pieces stabilized. Smith et al. (1993a, 1993b) found that debris removal mobilized more bed load and changed the location of pools and bars but did not change average pool characteristics. Hilderbrand et al. (1997) showed that additions of LWD caused substantial increases in the number and total area of pools and a corresponding reduction in total riffle area.

Our report stems from a comprehensive examination of LWD-stream interactions. We added LWD to a debris-poor, low-gradient stream and to a debris-poor, high-gradient stream in southwestern Virginia to examine the utility of LWD for stream restoration and enhancement. The research project was designed to test the potential for increasing pool number and area, for enhancing fish habitat, and for influencing benthic macroinvertebrates and storage of benthic detritus. Our objectives in this paper are to describe trends in channel adjustment relative to different orientations of experimentally added LWD and to describe factors contributing to $\log$ stability. We concentrate here only on the low-gradient stream because during the study period, channel modifications in the high-gradient stream were minimal (Hilderbrand et al. 1997) and flows were not sufficient to displace logs.

\section{M ethods}

North Fork Stony Creek is a third-order trout stream in the Appalachian Mountains of southwestern Virginia. Stony Creek has an average gradient just under $1 \%$, averages $5 \mathrm{~m}$ wide, and has a width-to-depth ratio of 7.8 (Hilderbrand et al. 1997). It flows primarily over sandstone and its bed is dominated by small and large gravels interspersed with sand and cobbles. Stony Creek flows through mature second-growth forest dominated by hemlock Tsugacanadensis and other conifers with a dense shrub understory. In the study reach, the channel is not confined on one side and overflows onto a floodplain during high discharges. Overbank flows occurred during our study and flows of this magnitude recur annually. Such flows divert energy from the channel and probably do not increase the potential for scour, but they may aid in displacing logs.

We divided the debris-addition area into two 250-m-long treatment sections. In one section, we placed LWD systematically according to our ideas of how to best manipulate stream habitats. In the other section, we placed logs according to a randomized design to mimic natural log drop. Details of $\log$ placement can be found in Hilderbrand et al. (1997). Fifteen of the 50 pieces added to each section had been selected at random from that section. Three permanent cross-sectional transects were established at each selected log, one transect $0.5 \mathrm{~m}$ upstream of the $\log$ and two at distances of 0.5 and $1.5 \mathrm{~m}$ downstream. We used a level and stadia rod to measure channel bed elevation at 0.5 $\mathrm{m}$ intervals along each transect from right-bank stake to left. Surveys were carried out at each log immediately after LWD placement in summer 1993 and again in summer 1994.

Changes in stream bed elevation were determined by comparing 1994 with corresponding 1993 values. An arbitrary minimum difference of $2 \mathrm{~cm}$ was required to be classified as a change. Average change in bed elevation was calculated for a total cross section. Net percent change in area (AA\%) and absolute percent change in area $(|\Delta A \%|)$ were calculated following Olson-Rutz and Marlow (1992). Each cross section was also subdivided into left-side, midchannel, and right-side portions to determine where aggradation or degradation occurred relative to $\log$ orientation. Some of the selected logs moved beyond their survey transects, and these transects were not considered in the analyses. All surveyed pieces spanned the entire channel.

Each year we surveyed 63 channel cross sections around $21 \operatorname{logs}$ classified as either dam perpendicular to flow, dam angled to flow direction, ramp angled upstream, ramp angled downstream, and ramp perpendicular to flow. Dams were flat on the bottom; ramps had one end propped on a bank. Log locations were determined by a mapping technique (Hilderbrand 1994) based on Cartesian geometry. We determined positions immediately after the addition of pieces and again 1 year later. Pieces moving $2 \mathrm{~m}$ (to allow for measurement errors) or more were labeled as unstable.

To determine why some logs moved and some did not, we used logistic regression to test factors affecting $\log$ stability. Log orientation variables were divided into categories of equal frequency and tested against whether or not the logs moved. Independent variables analyzed were log length, random versus systematic placement, log diameter, log volume, placement in pool versus in riffle, vertical orientation, and horizontal orientation. The G-test was used to determine if stability increased 


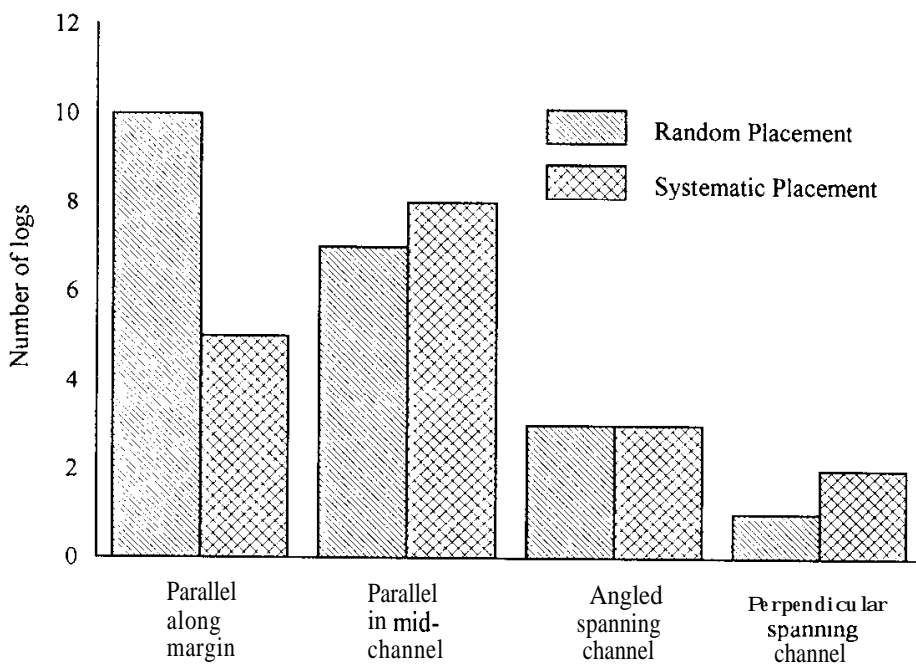

FIGURE I.-Final resting orientations of' logs that moved, by treatment section (random or systematic initial plaçement)

with the use of multiple log combinations instead of single logs. For unstable logs, multiple regression was used to examine factors governing distances moved and the G-test to examine final resting positions. Additionally, polytomous regression was used to determine the effects of specific $\log$ orientations on microscale stream channel changes. This procedure examined the effect of categorical $\log$ orientations (horizontal, vertical, etc.) on a categorical response. The procedure is similar to logistic regression, but three responses were possible (scour, fill, unchanged) instead of the binary response necessary for logistic regression. All results were judged against a significance level of $\alpha$ $=0.05$.

\section{Results}

\section{Log Stability}

There was no significant difference between treatment sections in the number of $\log$ s that moved (G-test, $P>0.05$ ). Logistic regression showed that no measured variables contributed significantly to $\log$ stability in either the random or systematic placement sections, but log length was nearly significant in each. A significant relationship between log length and stability emerged when the data from both sections was pooled. Logs longer than $7.5 \mathrm{~m}$ were significantly less likely to move than $\operatorname{logs}$ shorter than $5.5 \mathrm{~m}$, the average stream width (logistic regression, $P=0.024$ ), and nearly so for logs $5.5-6.5 \mathrm{~m}$ long $(P=0.07)$. No other variables influenced $\log$ stability to any degree.
Single $\operatorname{logs}$ moved as frequently as groups of $\operatorname{logs}$ (G-test, $P>0.05$ ). Groups of $\operatorname{logs}$ were significantly more likely to move together or remain stationary than to release individual pieces (G-test, $P=0.004)$. The average length of logs did not differ significantly between stable and mobile groups, but the longest piece in stable groups was significantly longer than the longest piece in mobile groups (analysis of variance, $P=0.023$ ). There was no difference in the length of the smallest $\log$ between the mobile and stable log groups $(P>0.05)$.

Log length was the only variable significantly associated with distance moved by unstable logs $\left(r^{2}=0.08 ; P=0.04\right)$. Including a length-squared term that formed a quadratic expression greatly increased the fit of the relationship, explaining $31 \%$ of the variance $\left(r^{2}=0.31 ; P<0.001\right)$. Longer pieces that moved traveled either short distances $(2 \mathrm{~m})$ or great distances $(>20 \mathrm{~m})$, but rarely between 3 and $20 \mathrm{~m}$. Unstable pieces ended in positions oriented parallel to stream flow significantly more often than in positions spanning the channel (Figure 1; G-test, $P<0.001$ ). There was no difference in number of parallel-oriented pieces between the channel margin and midchannel regions of the stream (G-test, $P>0.05$ ).

\section{Cross-sectional Trends}

Average $|\Delta A \%|$ for all cross sections were 5 $10 \%$ regardless of $\log$ orientation, demonstrating the ability of LWD to locally change channel features. However, high variability among cross sec- 
TABLE I.-Mean (SD) channel cross section changes in elevation $(\Delta E)$, percent change in area (AA\%) and absolute percent change in area $(|\Delta A|)$ for each $\log$ orientation. Negative values denote scouring and positive values indicate filling.

\begin{tabular}{lllrrrr}
\hline & & \multicolumn{2}{c}{ Dams } & \multicolumn{2}{c}{ Ramps } \\
\cline { 3 - 6 } Cross section & Measure & Angled & Perpendicular & Upstream & Downstream & Perpendicular \\
\hline Upstream & $\Delta E(\mathrm{~cm})$ & $198(2.96)$ & $-0.66(0.47)$ & $-2.01(2.92)$ & $-1.40(4.34)$ & $-2.48(5.29)$ \\
& $\Delta A \%$ & $3.16(5.21)$ & $-3.16(0.89)$ & $-2.34(1.77)$ & $-1 . Y Y(4.70)$ & $-3.50(5.66)$ \\
& $|\Delta A \%|$ & $7.21(2.83)$ & $5.26(0.56)$ & $5.28(1.36)$ & $6.47(2.05)$ & $7.67(2.28)$ \\
Middle & $\Delta E(\mathrm{~cm})$ & $2.15(4.85)$ & $-2.39(1.70)$ & $-4.67(4.53)$ & $-1.64(4.74)$ & $-2.61(3.84)$ \\
& $\Delta A \%$ & $-3.27(1.71)$ & $-6.75(9.35)$ & $-3.40(3.92)$ & $-1.91(6.14)$ & $-2.93(4.01)$ \\
& $|\Delta A \%|$ & $x .39(6.01)$ & $9.07(6.40)$ & $7.04(3.62)$ & $8.04(3.56)$ & $6.19(2.14)$ \\
Downstream & $\Delta E(\mathrm{~cm})$ & $5.64(9.17)$ & $-1.16(0.40)$ & $-2.15(4.22)$ & $-2.27(3.63)$ & $0.82(5.25)$ \\
& $\Delta A \%$ & $2.57(3.94)$ & $-2.01(1.78)$ & $-1.57(4.47)$ & $-1.82(5.15)$ & $-2.84(3.69)$ \\
& $|\Delta A \%|$ & $4.64(2.31)$ & $7.50(6.13)$ & $5.82(3.43)$ & $7.45(2.93)$ & $6.31(2.18)$ \\
\hline
\end{tabular}

tions resulted in no significant differences in mean elevation change, AA\%, and $|\Delta A \%|$ among log orientations. Nonetheless, some trends representing the majority of cross sections emerged. Net percent change in area (AA\%) indicated channel scour in association with all ramp orientations and with perpendicular dams (Table 1). Conversely, both the upstream and downstream cross sections of angled dams aggraded while the middle section scoured. Mean bed elevation followed the same patterns with a few exceptions. The greatest changes generally occurred in the middle cross sections immediately downstream of logs.

\section{Microscale Trends}

Results of polytomous regression revealed no significant patterns of channel adjustment at the microscale relative to $\log$ orientation. The following trends may have heuristic value, however.

Scour patterns were similar for all three ramp orientations (Figure 2). Most of this scour occurred immediately downstream of $\operatorname{logs}$ and along the sides of the channel. Ramps oriented upstream induced scour on both sides of the channel in all cross sections and in midchannel immediately below logs.

Downstream-oriented ramps brought scour along both sides, but midchannel areas remained unchanged. Maximum scour depth occurred downstream of the log and on the right side of the channel. Depth of scouring decreased upstream on the right side. Scour occurred immediately above and below logs near the tip of each ramp, but not in the cross section furthest downstream.

Scour patterns followed a left-to-right downstream diagonal for ramps oriented perpendicular to flow (Figure 2). Scour occurred above the log tips on the left side. Aggradation occurred on the right side upstream of ramps whereas the left side did not change downstream of ramp tips.

Dams oriented perpendicular to flow demonstrated a virtual mirror image of perpendicular ramps with the scour diagonal running right to left (Figure 2). Filling occurred immediately downstream of logs on the right side.

Angled dams aggraded along both sides at all three cross sections and in midchannel upstream of $\operatorname{logs}$ (Figure 2). Midchannel scour occurred downstream of logs. Every cell of every cross section for this orientation experienced an average elevational change.

\section{D iscussion}

Log length played an important role in the stability of LWD pieces we installed. Logs shorter than the average channel width $(5.5 \mathrm{~m})$ moved significantly more frequently than $\operatorname{logs} 1.5-2$ times the average channel width. This trend has been shown in several other studies as well (Bilby 1984; Lienkaemper and Swanson 1987; Robison and Beschta 1990). Lienkaemper and Swanson (1987) reported an inverse relationship between $\log$ length and downstream movement in Oregon streams; all pieces moving more than $10 \mathrm{~m}$ were shorter than the average bankfull width. Wood may be easily displaced at high discharges, but pieces longer than the channel width appear more likely to become jammed against riparian vegetation or channel obstructions. Bilby (1984) found that longer pieces were often jammed against objects at several points across the channel and along banks. This greatly reduced the chance of movement, as did the degree of anchoring by the obstruction (Bilby 1984; Lienkaemper and Swanson 1987).

Previous studies have shown an inverse relationship between $\log$ size and distance moved (Bil- 


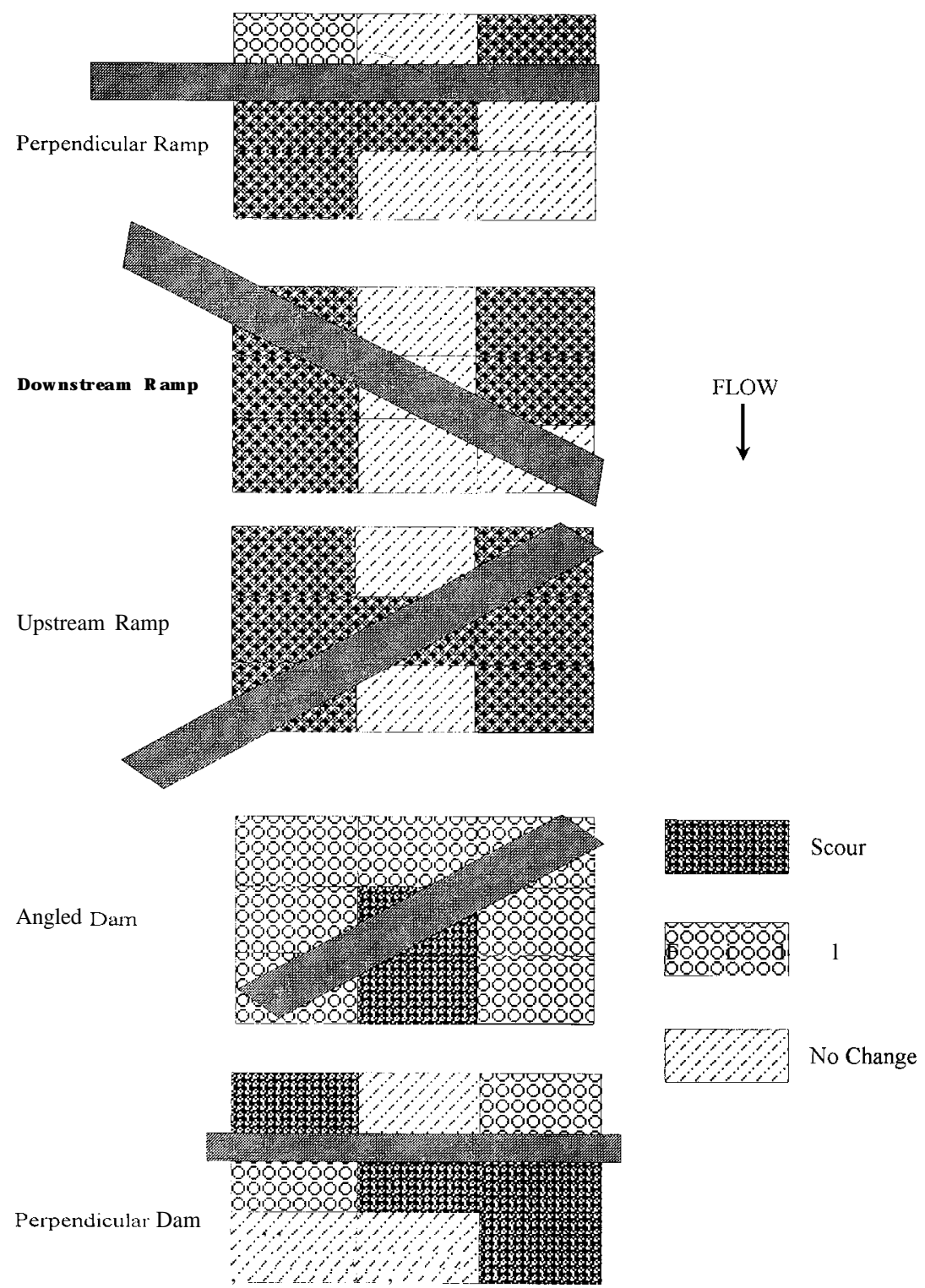

FIGURE 2.-Average changes in channel elevation for different log orientations. Dams were flat on the streambed; ramps had one end propped on the stream bank.

by 1984; Lienkaemper and Swanson 1987). Though the log that moved the farthest in our study was the shortest $\log$, the majority of $\log s$ that moved the farthest distances were the longer logs. Longer logs were more stable; however, once these logs broke free, they traveled a long way, as indicated by the quadratic term in the regression equation describing distance moved. Long pieces may have more inertia once moving and require more obstructions to stop. The majority of unstable logs came to rest parallel to the direction of flow.
This agrees with the findings of Hogan (1987) who reported that stable pieces occurred perpendicular or angled to the channel whereas unstable pieces were parallel.

Aggregates of LWD may be more effective in creating and maintaining pools than single pieces (Carlson et al. 1990). Aggregates moved at the same frequency as individual pieces, but the longest $\log$ in the aggregates that remained stable was significantly longer than the longest $\log$ in the unstable aggregates. Lienkaemper and Swanson 
(1987) found that many stationary pieces were protected by anchored pieces. This suggests that managers may use a large anchoring log on the downstream end of an aggregate and use smaller pieces within the channel to modify channel attributes of interest. However, more information and monitoring is needed before widespread implementation of this technique can be justified.

\section{Debris Orientation and Channel Change}

This study and others (Bilby 1984; Smith et al. 1993b; Hilderbrand et al. 1997) have clearly shown that LWD alters channel morphology. The present issue is how log orientation influences channel pattern. The lack of statistical significance in our analyses of debris orientation and channel change imply that orientation is irrelevant. We nonetheless feel that orientation is an important consideration. Although none of the logs selected for detailed cross sections created pools, all seven of the pools elsewhere in the study sections were formed by $\operatorname{logs}$ oriented as dams (Hilderbrand et al. 1997). Our sample sizes were small and variability was high, but the trends reported for any given orientation represent the majority of the logs measured.

For entire cross sections, ramps of all orientations increased channel scouring both above and below logs. Scour frequency was greatest immediately below the log, diminishing 1-2 m downstream. The low frequency of aggradation below logs implies that most bed materials were redistributed more than $2 \mathrm{~m}$ downstream.

Average streambed elevation for cross sections around dams did not change. However, the microscale measures showed that more spatial cells changed elevation than remained unchanged. This discrepancy suggests that degradation in one part of the cross section was countered by aggradation in another section. In addition to the possible lateral redistribution of bed load, deposition of bed load from upstream could balance bed load exported from the cross sections. Dams laying flat on the channel bed alter hydraulic conditions, constricting flow through the thalweg and causing scour in some places and deposition in other places. Whatever the cause, the discrepancy in results highlights the importance of choosing the appropriate observational scale for the question asked.

In a flume study involving dowels, Cherry and Beschta (1989) found scour area was greatest when dowels were held flat on the bed, and maximum scour depth occurred near the middle of the dowels. In the present study, mean maximum scour depth occurred near the middle of the logs (midchannel) for both dam orientations, but scour area was greatest for ramps. Indeed, the only scour around angled dams was in midchannel below logs, whereas cells on both sides aggraded above and below the logs. The difference was most likely due to the dams on Stony Creek spanning the entire channel width, whereas the dowels used by Cherry and Beschta (1989) extended only to midchannel. Dowels allowed unrestricted flow through half of the flume whereas dams on Stony Creek influenced flow over all parts of the channel width. In the flume, scour most likely began at the midchannel tip of the dowel and undercut along the dowel's length. Conversely, in Stony Creek, the thalweg was near midchannel for all but one of the dams, so the only clear flow path under dams would be in midchannel.

The dominant substrate classes in Stony Creek are large and small gravels. These substrates are more easily moved than cobbles and boulders associated with higher-gradient trout streams in the Appalachian Mountains, and they should, in theory, undergo larger changes. The channel adjustment patterns observed in this study (Figure 2) can provide general guidance for those wishing to manage filling and scour via LWD so as to increase the number and depths of pools. Our sample sizes for each orientation of $\log$ were small, ranging from two perpendicular dams to seven downstream ramps. Other factors such as thalweg position, pools versus riffles, channel curvature, and other logs may mask or interact with each other to produce the observed results, but we know of no information pertaining to these relationships and our sample sizes were too small to address them. Given the variability in stream environments, the results we describe are only trends. They offer a useful starting point, but a much larger sample size is needed to produce definitive guidelines for LWD placement.

\section{Acknowledgments}

We thank G. Annis, J. Harefield, and T. Huffman of the Blacksburg District, Jefferson National Forest, for their assistance in the LWD additions, and K. Newman, M. Underwood, and S. White for field assistance. S.Barras, K. Engelhardt, and two anonymous reviewers provided useful comments and criticisms of this manuscript. Funding for this project was provided by the U.S. Forest Service Southern Research Station under cooperative agreement 29-825. 


\section{$R$ eferences}

Anderson, N. H., J. R. Sedell, and F. J. Triska. 1978. The role of aquatic invertebrates in processing of wood in coniferous forest streams. American Midland Naturalist 100:64-82.

Beschta, R. L. 1983. The effects of large organic debris upon channel morphology: a flume study. Pages 8.63-8.78 in D. B. Simons, editor. Symposium on erosion and sedimentation. Simons, Li, and Associates, Fort Collins, Colorado.

Bilby, R. E. 1984. Removal of woody debris may affect stream channel stability. Journal of Forestry 82: $609-613$.

Bilby, R. E., and G. E. Likens. 1980. Importance of organic debris dams in the structure and function of stream ecosystems. Ecology $61: 1107-1113$.

Bilby, R. E., and J. W. Ward. 1989. Changes in characteristics and function of woody debris with increasing size of streams in western Washington. Transactions of the American Fisheries Society 118 : 368378 .

Bisson, P. A., and eight coauthors. 1987. Large woody debris in forested streams in the Pacific Northwest: past, present, and future. Pages 143-190 in E. 0. Salo and T. W. Cundy, editors. Proceedings of symposium on streamside management: forestry and fishery interactions. University of Washington, Institute of Forest Resources, Seattle.

Carlson. J. Y.. C. W. Andrus, and H. A. Froehlich. 1990. Woody debris. channel features. and macroinvertebrates of streams with logged and undisturbed riparian timber in northeastern Oregon, USA. Canadian Journal of Fisheries and Aquatic Sciences 47:1103-1111

Cherry. J., and R. L. Beschta. 1989. Coarse woody debris and channel morphology: a flume study. Water Resources Bulletin 25: 103 I-1036.

Dolloff, C. A. 1986. Effects of stream cleaning on juvenile coho salmon and Dolly Varden in southeast Alaska. Transactions of the American Fisheries Society 115:743-755

Hilderbrand, R. H. 1994. Relations between large woody debris, physical habitat, and benthic macroinvertebrates in Appalachian Mountain streams. Master's thesis. Virginia Polytechnic Institute and State University, Blacksburg.

Hilderbrand, R. H.. A. D. Lemly. C. A. Dolloff, and K. H. Harpster. 1997. Effects of large woody debris placement on stream channels and benthic macroinvertebrates. Canadian Journal of Fisheries and Aquatic Sciences 54:93 1-939.

Hogan, D. L. 1987. The influence of large organic debris on channel recovery in the Queen Charlotte Islands. British Columbia, Canada. Pages 3433353 in R. L. Beschta. T. Blinn. G. E. Grant. G.G. Ice, and F. J. Swanson. editors. Erosion and sedimentation in the
Pacific Rim. International Association of Hydrological Sciences, Publication 165, Wallingford, UK.

Keller, E. A., and F. J. Swanson. 1979. Effects of large organic material on channel form and fluvial processes. Earth Surface Processes and Landforms 4: 361-380.

Lienkaemper, G. W., and F. J. Swanson. 1987. Dynamics of large woody debris in streams in old-growth Douglas-fir forests. Canadian Journal of Forest Research 17:150-156

Megahan, W. F. 1982. Channel sediment storage behind obstructions in forested drainage basins draining the granitic bedrock of the Idaho batholith. Pages 114 121 in F. J. Swanson, R. J. Janda, T.Dunne, and D. N. Swanston, editors. Sediment budgets and routing in forested drainage. U.S. Forest Service General Technical Report PNW- 141.

O'Connor, N. A. 1991. The effects of habitat complexity on the macroinvertebrates colonising wood substrates in a lowland stream. Oecologia 85:504-512.

Olson-Rutz, K. M., and C. B. Marlow. 1992. Analysis and interpretation of stream channel cross-sectional data. North American Journal of Fisheries Management 12:55-61.

Robison, E. G., and R. L. Beschta. 1990. Characteristics of coarse woody debris for several coastal streams of southeast Alaska, USA. Canadian Journal of Fisheries and Aquatic Sciences 47:1684-1693.

Smith, R. D., R. C. Sidle, and P. E. Porter. 1993a. Effects on bedload transport of experimental removal of woody debris from a forest gravel-bed stream. Earth Surface Processes and Landforms 18:455-468.

Smith, R. D., R. C. Sidle, P. E. Porter, and J. R. Noel. 1993b. Effects of experimental removal of large woody debris on the channel morphology of a forest, gravel-bed stream. Journal of Hydrology (Amsterdam) 152:153-178.

Smock, L. A., G. M. Metrler, and J. E. Gladden. 1989. Role of debris dams in the structure and functioning of low-gradient headwater streams. Ecology 70 : 764-775.

Speaker, R., K. Moore, and S. Gregory. 1984. Analysis of the process of retention of organic matter in stream ecosystems. Internationale Vereinigung für Theoretische und Angewandte Limnologie Verhandlungen 22:1835-1841.

Triska, F. J., and K. Cromack. 1980. The role of wood debris in forests and streams. Pages 171-190 in R. H. Waring, editor. Forests: fresh perspectives from ecosystem analysis. Oregon State University, Corvallis.

Trotter, E. H. 1990. Woody debris. forest-stream succession, and catchment geomorphology. Journal of the North American Benthological Society 9: 141156.

Received April 18, 1997 Acccptrd September 3, 1997 
